\title{
Covariance analysis of sugarcane variety experiments (Saccharum spp.) in contrasting environments
}

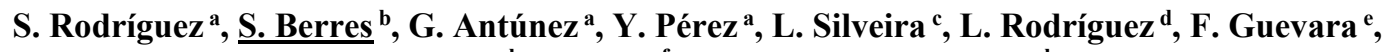 \\ I. Expósito ${ }^{\text {a }, \text { C. Torres-Ulloa }}{ }^{\text {b }}$, S. Valle ${ }^{\text {f }}$, M.C. Conci ${ }^{g}$, G. Cupri $^{\text {h }}$ and A. Mercado $^{\text {a }}$ \\ ${ }^{a}$ University of Granma, Cuba, ${ }^{b}$ Catholic University of Temuco, Chile,${ }^{c}$ CAEP, USA, ${ }^{d}$ University of the \\ Science and Arts of Chiapas, Mexico, ${ }^{e}$ Autonomous University of Chiapas, Mexico, ${ }^{f}$ Amazon State \\ University, Ecuador, ${ }^{g}$ National University of Villa María. Argentina, ${ }^{h}$ National University of the Northeast \\ of the Province of Buenos Aires, Argentina. \\ Email:sberres@uct.cl
}

\begin{abstract}
This contribution presents the results of a covariance analysis of experiments with sugarcane varieties (Saccharum spp.) in contrasting environments on a Vertisol soil type, both under normal soil conditions and in flooding conditions. The varieties of the used sugarcane were commercial varieties of the cuban sugarcane breeding program, C87-51, C1051-72, C120-78, C8612, C86-456 and C90-469.

Plant cane and first ratoon cane, both at 12 months of age, were evaluated in a Randomized Complete Block Design (RCBD) with five replications. The first ratoon cane corresponds to a plant in its second season. It is formed during the first harvest of a plant, when the lower part of the plant is left uncut, such that ratoons can grow from the buds. First ratoon cane provides a faster maturing but delivers a less amount of yield.

The dependent variable was the cane yield measured in tonnes (metric tons) per hectare (tcane ha ${ }^{-1}$ ). As a covariate variable of the model the millable stalk number plot was chosen. The two variables were evaluated at the age of 12 months.

The results demonstrate the usefulness of a covariance analysis in the presence of a quantitative variable, which affects the experimental units or plots. In particular, adjusted average values of agricultural performance and a correct ordering of the merit of these variables could be obtained. Thereby, a bias in the results is avoided, which might occur if the variety experiments are evaluated in contrasting environments.

The covariance analysis minimizes the variability among experimental units by adjusting their values to a common value of the covariate. The use of the covariate reduced the mean square error in the analysis and increased the reliability of the experimental results. If the millable stalk number per plot were not measured, then the variation of the cane yield in dependence on the impact of the specific crop-plot combinations could not be determined and would be included in the error term (mean square error). The use of a covariate reduced the mean square error in the analysis and increased the significance of the experimental results in plant cane and in the first ratoon cycle.

Under the effects of water excesses in the soil a marked reduction of the cane yield could be detected for all varieties. Thereby, the varieties C1051-73, C87-51 and C120-78 were affected most, and the other group integrated by C90-469, C86-12 and C86-456 in a significantly smaller proportion. This evidences that the latter group of varieties counts with a morphophysiology and biochemical mechanisms that make them adapt better to flooded soils.
\end{abstract}

No marked difference between the first and second sugarcane cutting could be detected, except a decrease in the cane yield when the number of cuttings is increased. Therefore, similar results were obtained for the plant cane and in the first ratoon cycle, with only slight differences in the magnitudes.

Keywords: Covariance analysis, sugarcane, flooding, contrasting environments 


\section{INTRODUCTION}

\subsection{Water excess in the soil and cane yield in sugar cane (Saccharum spp.)}

Sugarcane contributes to more than $72 \%$ of the world production of sugar (WSS, 2003). During the period from 1960 to 1999 , the average productivity has increased from 75 to 95 tonnes of sugarcane per hectare and from 5 to 12 tonnes of pol per hectare (Cock, 2003). The pol of the cane is the sucrose concentration in the juice of the stems measured by a polarimeter.

Globally important growing areas typically have a poor drainage, which causes serious problems for the soil and crop management when the soil alters its physical-chemical properties and the crop reduces its agribusiness yield (Deren et al., 1993).

Excess moisture in the soil of sugar cane plantations leads to considerable losses in the cane yield due to poor aeration and increased carbon dioxide production. A low oxygen concentration in the soil inhibits the formation of the root system and thus reduces the absorption of water and nutrients (Reynoso, 1963; Humbert, 1965).

For instance, in the State of Louisiana, USA, in many of the areas that are planted with sugar cane, conditions of over-wetting prevail. Samuels (1979) found that the floods affected the process of cane tillering in the plant cane and first ratoon in various genotypes.

Out of the three main parameters determining the cane yield in the plant cane cycle, namely stalk longitude, stalk diameter and the stalk number, the most affected one in flooding conditions was the stalk number (Rodríguez, 2008). It proportionally affects the millable stalk per unit of area. Therefore, in order to increase the statistical precision, in the evaluation of field experiments in sugar cane under flooding conditions, it is highly recommended to chose the millable stalk number per unit area as concomitant or covariate variable.

\subsection{Analysis of covariance in the agricultural experimentation}

In order to improve the accuracy of the comparisons between treatments, complementary to techniques of controlling the structure of plots, the analysis of covariance helps to make predictions more robust. In the covariance analysis, the covariate is a variable that can be observed for each of the experimental units. If it is linearly related to the variable under study then it can be used to correct the response variable, before making comparisons between treatments. This technique can be interpreted as a combination of the analysis of variance and linear regression. It can be used regardless of the structure of plots or treatments that characterize the experiment (Balzarini et al., 2008).

The analysis of covariance is a very important statistical method in experimentation, especially for the agricultural sciences, but for various reasons it is not used in many occasions. It combines variance analysis with regression analysis in order to reduce the variability that can be explained by the covariate variable; it also adjusts treatment measures and estimates the effect of the independent variable (treatment) on the dependent variable with more precision (Wishart, 1936; DeLury, 1948).

The most important uses of the covariance analysis are: (a) to control the error and to increase the precision, (b) to adjust treatment measures from the dependent variable to the different groups of values of corresponding independent variables, (c) to interpret the nature of the effects of the treatments, and (d) to divide a total covariance or sum of crossed products in components (Finney, 1946; Federer and Schlottfeldt, 1954; Outhwaite and Rutherford, 1955; Fairfield, 1957; Rayner et al., 1991 and Badii et al., 2008).

\section{METHODS}

The experiment was developed in the Sugar Enterprise 'Grito de Yara', located in the Río Cauto municipality, in Granma County, Cuba. The soil belongs to the Vertisols group according to the World Reference Base (Driessen et al., 2001); alternatively, it can be classified as a Typic Haplustert according to the Soil Survey Staff (2003).

The experiment was carried out following the norms and procedures determined by the 'Program of Genetic Improvement of Sugarcane' in Cuba, of the 'National Institute of Sugarcane Research' (INICA, 2002), in a Randomized Complete Block Design (RCBD) with five replications, with plots of $48 \mathrm{~m}^{2}$, consisting of 4 furrows of $7.5 \mathrm{~m}$ length and $1.60 \mathrm{~m}$ distance between the furrows. Two experiments were rolled out simultaneously on the same soil, one experiment in non-flooding conditions and the second in flooding 
conditions. Each experiment was separated $50 \mathrm{~m}$ from the other to avoid lateral water infiltrations; in this separation interval 10 gutters of $0.50 \mathrm{~m}$ depth separated by $1 \mathrm{~m}$ were built.

The following sugar cane genotypes were used, the parentals are indicated in parenthesis: C86-456 (PR980 x Ja60-5), C90-469 (Ja60-5 x C87-51), C86-12 (unknown partentals), C87-51 (Co281 x POJ2878), C1051-73 (B42231 x C431-62) and C120-78 (Co421 x C87-51) (Bernal et al., 1997; Jorge et al., 2004). The experiment was started in January 2002 and the cut realized at 12 months of age. The evaluated crop cycles were the plant cane crop (first cutting) and the first ratoon crop (second cutting). The dependent variable was cane yield in tonnes of cane per hectare $\left(\mathrm{TCH}\right.$; tcane $\left.\mathrm{ha}^{-1}\right)$. As a covariate variable the millable stalk number per plot was chosen. Both variables were registered at the moment of cutting (12 months of age in plant cane crop and in the first ratoon).

\section{MATHEMATICAL MODEL}

The mathematical model to describe the experimental data is given by Snedecor and Cochran (1980),

$$
Y_{i j}=\mu+\alpha_{i}+\mathrm{b}_{j}+\beta_{i}\left(X_{i j}-\overline{\mathrm{X}}\right)+E_{i j}
$$

Here, $\mathrm{Y}_{\mathrm{ij}}$ is the cane yield of the $i$-th variety in the $j$-th block, $\mu$ is the overall mean of the cane yield, $\mathrm{X}_{\mathrm{ij}}$ is the millable stalk number per plot (auxiliary variable or covariate) in the same plot, $\alpha_{\mathrm{i}}$ is the effect of the $i$-th variety, $\mathrm{b}_{\mathrm{j}}$ is the effect of the $j$-th block, $\beta_{\mathrm{i}}$ is the slope of the $i$-th variety, $\overline{\mathrm{X}}$ is the overall mean over all $\mathrm{X}_{\mathrm{ij}}$, and $E_{i j}$ is the experimental error. If the millable stalk number $\left(X_{i j}\right)$ in each plot was not measured, then the variation of the cane yield $\mathrm{Y}_{\mathrm{ij}}$ due to $\beta_{i}\left(\mathrm{X}_{\mathrm{ij}_{-}-} \mathrm{X}\right)$ could not be determined and would be included in the error term such that variance analysis model would become

$$
Y_{i j}=\mu+\alpha_{i}+\mathrm{b}_{j}+E_{i j}
$$

The analysis of variance and covariance without and with covariates (stalk number per plot) was used to estimate the effect of the covariate on the cane yield. The analysis of variance and the analysis of mean square covariance error is compared for both models under flooding and non-flooding soil conditions. The analysis provides source, mean square and the value of probability at five percent ( $\mathrm{p}$ value). To compare the significance level of the mean for all varieties, the Tukey test was used at 5 percent level. The statistical analysis was done by using the Infostat software (Di Rienzo et al., 2013).

\section{RESULTS}

In this section reports the results of a variance analysis for the cane yield (tcane per ha-1) carried out in order to study the effect of choosing the stalk number per plot as covariate. Four cases are tested, corresponding to the possible combinations of the two considered soil conditions, namely flooding (F) and non-flooding (NF) soil conditions, with the two considered cane cycles, namely plane cane and first ratoon cane. In the tables, several statistical parameters of the analysis of variance are reported. A significant difference in the cane yield is visualized by different letters, specifically by ' $a$ ' and ' $b$ ' to identify the two predominant classes.

In the plant cane cycle at age of 12 months under non-flooding conditions of the soil, the use of the millable stalk number as covariate did not lead to a decrease of the value of the square mean error, compared to an analysis in absence of the covariate, see Table 1. This indicates the existence of a homogeneous millable stalk population for plots under appropriately small humidity conditions in the soil for all six varieties, without a significant linear relationship $(\mathrm{p}=0,9546)$.

In the plant cane cycle, the water excesses in the soil caused a high variation in the population of millable stalks, leading to a significant effect on the cane yield, see Table 2. Namely, between the cane yield and the millable stalk number per plot there is a significant linear relationship $(\mathrm{p}<0,0001)$ of positive slope (coef. $=$ 0.19). As the millable stalk number per plot was different for each one of the varieties, its effect on the cane yield is discounted. For each variety the average values of cane yield and its standard error are adjusted to the millable stalk number as covariate. Under flooding conditions the inclusion of the covariate leads to higher mean values of cane yield in the varieties C1051-73, C87-51 and C120-78 and to lower mean values for the varieties C90-469, C86-12 and C86-456. 
Table 1. Variance analysis for cane yield ( $\mathrm{TCH}$; tcane per ha-1) without and with covariate (stalk number per plot) in plane cane at 12 months of age in non-flooded soil conditions (NF). MS is mean square, $p$-value is the probability at 0,005 and the coefficient ('Coef.') of linear regression. Different letters indicate significant differences to 0,005 percent of probability ( $\mathrm{Sig})$.

Analysis of variance without covariate. NF

Analysis of variance with covariate. NF

\begin{tabular}{cccc|cccc} 
Source & MS & p-value & Coef. & Source & MS & p-value & Coef. \\
\hline Varieties & 514,55 & $<0,0001$ & - & Varieties & 90,79 & 0,0448 & - \\
- & - & - & - & SN per plot & 0,12 & 0,9546 & 0,01 \\
Error & 35,63 & & & Error & 37,17 & &
\end{tabular}

Multiple comparison test of means. Tukey.

\begin{tabular}{ccc|ccc}
\multicolumn{2}{c|}{ Without covariate. Non-flooding $(\mathbf{N F})$} & \multicolumn{3}{c}{ With covariate. Non-flooding (NF) } \\
Varieties & Means \pm SE & Sig & Varieties & Means \pm SE & Sig \\
\hline C120-78 & $53,44 \pm 2,67$ & $\mathrm{a}$ & $\mathrm{C} 120-78$ & $53,67 \pm 4,84$ & $\mathrm{a}$ \\
$\mathrm{C} 87-51$ & $54,28 \pm 2,67$ & $\mathrm{a}$ & $\mathrm{C} 87-51$ & $54,45 \pm 3,99$ & $\mathrm{a}$ \\
$\mathrm{C} 1051-73$ & $55,14 \pm 2,67$ & $\mathrm{a}$ & $\mathrm{C} 1051-73$ & $55,33 \pm 4,24$ & $\mathrm{a}$ \\
$\mathrm{C} 86-456$ & $70,12 \pm 2,97$ & $\mathrm{~b}$ & $\mathrm{C} 86-456$ & $70,05 \pm 2,97$ & $\mathrm{~b}$ \\
$\mathrm{C} 86-12$ & $70,78 \pm 2,67$ & $\mathrm{~b}$ & $\mathrm{C} 86-12$ & $70,70 \pm 3,07$ & $\mathrm{~b}$ \\
$\mathrm{C} 90-469$ & $76,22 \pm 2,67$ & $\mathrm{~b}$ & $\mathrm{C} 90-469$ & $75,78 \pm 8,04$ & $\mathrm{~b}$
\end{tabular}

Table 2. Variance analysis for cane yield (TCH; tcane per ha-1) without and with covariate (stalk number per plot) in plan cane with 12 months of age in flooded soil conditions (F). MS is mean square, p-value is the probability at 0,005 and the coefficient ('Coef.') of linear regression. Different letters indicate significant differences to 0,005 percent of probability (Sig).

\begin{tabular}{l|l} 
Analysis of variance without covariate. $F \quad$ Analysis of variance with covariate. $F$
\end{tabular}

\begin{tabular}{cccc|cccc} 
Source & MS & p-value & Coef. & Source & MS & p-value & Coef. \\
\hline Varieties & 1012,70 & $<0,0001$ & - & Varieties & 103,08 & $<0,0001$ & - \\
- & - & - & - & SN per plot & 443,92 & $<0,0001$ & 0,19 \\
Error & 24,27 & - & - & Error & 6,03 & &
\end{tabular}

Multiple comparison test of means. Tukey.

\begin{tabular}{ccc|ccc}
\multicolumn{3}{c}{ Without covariate. Flooding (F) } & \multicolumn{3}{c}{ With covariate. Flooding (F) } \\
Varieties & Means \pm SE & Sig & Varieties & Means \pm SE & Sig \\
\hline C120-78 & $38,40 \pm 2,20$ & $\mathrm{a}$ & $\mathrm{C} 120-78$ & $44,55 \pm 1,31$ & $\mathrm{a}$ \\
$\mathrm{C} 1051-73$ & $41,62 \pm 2,20$ & $\mathrm{a}$ & $\mathrm{C} 1051-73$ & $47,68 \pm 1,27$ & $\mathrm{a}$ \\
$\mathrm{C} 87-51$ & $42,28 \pm 2,20$ & $\mathrm{a}$ & $\mathrm{C} 87-51$ & $47,77 \pm 1,31$ & $\mathrm{a}$ \\
$\mathrm{C} 86-12$ & $63,50 \pm 2,20$ & $\mathrm{~b}$ & $\mathrm{C} 86-12$ & $60,16 \pm 1,16$ & $\mathrm{~b}$ \\
$\mathrm{C} 86-456$ & $65,56 \pm 2,67$ & $\mathrm{~b}$ & $\mathrm{C} 86-456$ & $60,48 \pm 1,56$ & $\mathrm{~b}$ \\
$\mathrm{C} 90-469$ & $70,00 \pm 2,20$ & $\mathrm{~b}$ & $\mathrm{C} 90-469$ & $60,71 \pm 123$ & $\mathrm{~b}$
\end{tabular}

As general tendency the same results were obtained for the first ratoon cycle, but in different magnitudes, see Tables 3 and 4 for comparison. This seems to evidence that there is not a marked influence between the first and second sugarcane cutting, except a decrease in the cane yield as the number of cuttings is increased.

Under the effects of water excesses in the soil, a marked reduction of the cane yield could be observed also for the first ratoon cycle. As for the plant cane cycle, the yield descent was more noticeable in the varieties C1051-73, C87-51 and C120-78 and occurred in less proportion in the other group integrated by C90-469, C86-12 and C86-456. This evidences that the latter group of varieties presents a morphophysiology and biochemical mechanisms that make them adapt better to flooded soils, independently of the overall plant age.

Stressed environments, like the excess of water in the soil, cause significant alterations in the millable stalk number per unit area. Therefore, it is recommended to choose the millable stalk number per plot in crops like sugar cane as covariate, because this quantitative variable essentially determines the cane yield. 
Table 3. Variance analysis for cane yield ( $\mathrm{TCH}$; tcane per ha-1) without and with covariate (stalk number per plot) in first ratoon with 12 months of age in non-flooded soil conditions (NF). MS is mean square, p-value is the probability at 0,005 and the coefficient ('Coef.') of linear regression. Different letters indicate significant differences to 0,005 percent of probability (Sig).

\begin{tabular}{cccc|cccc}
\multicolumn{2}{c}{ Analysis of variance without covariate. NF } & \multicolumn{4}{c}{ Analysis of variance with covariate. NF } \\
Source & MS & p-value & Coef. & Source & MS & p-value & Coef. \\
\hline Varieties & 568,88 & $<0,0001$ & - & Varieties & 322,01 & $<0,0001$ & - \\
- & - & - & - & SN per plot & 72,96 & & \\
Error & 21,18 & - & - & Error & 19,55 & 0,0658 & $-0,08$
\end{tabular}

Multiple comparison test of means. Tukey.

\begin{tabular}{ccc|ccc}
\multicolumn{2}{c}{ Without covariate. Non-flooding (NF) } & \multicolumn{3}{c}{ With covariate. Non-flooding (NF) } \\
Varieties & Means \pm SE & Sig & Varieties & Means \pm SE & Sig \\
\hline C120-78 & $45,44 \pm 2,09$ & $\mathrm{a}$ & $\mathrm{C} 120-78$ & $43,55 \pm 2,21$ & $\mathrm{a}$ \\
$\mathrm{C} 1051-73$ & $47,60 \pm 2,09$ & $\mathrm{a}$ & $\mathrm{C} 87-51$ & $46,15 \pm 2,38$ & $\mathrm{a}$ \\
$\mathrm{C} 87-51$ & $48,72 \pm 2,09$ & $\mathrm{a}$ & $\mathrm{C} 1051-73$ & $46,31 \pm 2,09$ & $\mathrm{a}$ \\
C86-12 & $62,82 \pm 2,09$ & $\mathrm{~b}$ & $\mathrm{C} 86-12$ & $64,08 \pm 2,08$ & $\mathrm{~b}$ \\
C86-456 & $63,74 \pm 2,09$ & $\mathrm{~b}$ & $\mathrm{C} 86-456$ & $64,90 \pm 2,07$ & $\mathrm{~b}$ \\
C90-469 & $71,18 \pm 2,09$ & $\mathrm{~b}$ & $\mathrm{C} 90-469$ & $74,51 \pm 2,62$ & $\mathrm{~b}$
\end{tabular}

From an agro-productive point of view, the millable stalks, where the sugars are stored, are the most important organ of the sugar cane. The stalks represent among 50 to $80 \%$ of the total biomass that exists in a sugar cane plantation. On the other hand, the recoverable sugar produced by unit area at given time is the economically useful product of the sugar cane. The quantity of this sugar depends on the production of stalks and on its sucrose content (Amaya et al., 1995).

Table 4. Variance analysis for cane yield $\left(\mathrm{TCH}\right.$; tcane per ha ${ }^{-1}$ ) without and with covariate (stalk number per plot) in first ratoon with 12 months of age in flooded soil conditions (F). MS is mean square, p-value is the probability at 0,005 and the coefficient ('Coef.') of linear regression. Different letters indicate significant differences to 0,005 percent of probability (Sig).

\begin{tabular}{cccc|lccc}
\multicolumn{2}{c}{ Analysis of variance without covariate. $\mathbf{F}$} & \multicolumn{4}{c}{ Analysis of variance with covariate. F } \\
Source & MS & p-value & Coef. & Source & MS & p-value & Coef. \\
\hline Varieties & 550,65 & $<0,0001$ & - & Varieties & 57,58 & 0,0141 & - \\
- & - & - & - & SN per plot & 154,80 & & \\
Error & 21,57 & - & - & Error & 15,78 & 0,0047 & 0,14
\end{tabular}

Multiple comparison test of means. Tukey.

\begin{tabular}{ccc|ccc}
\multicolumn{3}{c}{ Without covariate. Flooding (F) } & \multicolumn{3}{c}{ With covariate. Flooding (F) } \\
Varieties & Means \pm SE & Sig & Varieties & Means \pm SE & Sig \\
\hline C87-51 & $37,76 \pm 2,08$ & $\mathrm{a}$ & C $87-51$ & $41,84 \pm 2,20$ & $\mathrm{a}$ \\
$\mathrm{C} 1051-73$ & $39,42 \pm 2,08$ & $\mathrm{a}$ & $\mathrm{C} 1051-73$ & $41,95 \pm 1,95$ & $\mathrm{a}$ \\
$\mathrm{C} 120-78$ & $39,46 \pm 2,08$ & $\mathrm{a}$ & $\mathrm{C} 120-78$ & $44,20 \pm 2,33$ & $\mathrm{a}$ \\
$\mathrm{C} 86-12$ & $54,24 \pm 2,08$ & $\mathrm{~b}$ & $\mathrm{C} 86-12$ & $52,07 \pm 1,91$ & $\mathrm{~b}$ \\
$\mathrm{C} 86-456$ & $55,32 \pm 2,08$ & $\mathrm{~b}$ & $\mathrm{C} 86-456$ & $52,41 \pm 2,00$ & $\mathrm{~b}$ \\
C90-469 & $62,38 \pm 2,08$ & $\mathrm{~b}$ & $\mathrm{C} 90-469$ & $56,10 \pm 2,68$ & $\mathrm{~b}$
\end{tabular}

\section{CONCLUSION AND DISCUSSION}

The use of covariance analysis in agricultural experiments with crops, where the stalk number determines the agricultural yield (sugar cane, rice, sorghum, etc.), is very helpful to obtain results with smaller experimental error and a better adjustment of the mean values of the different treatments. These results increase their relevance if there are prevailing environmental conditions as the stress of water excess in the soil affects the stalk number per experimental unit. 
If the millable stalk number per plot was not measured, then the variation of the cane yield $Y_{i j}$ due to the then missing term $\beta_{i}\left(\mathrm{X}_{\mathrm{ij}_{-}-} \overline{\mathrm{X}}\right)$ would be included in the error term as mean square error. The use of a covariate reduces the mean square error in the analysis and increases the efficiency and accuracy of the interpretation of the experimental results.

Given the significant impact of water content, one might ask whether the water content eventually suits as a covariate. Well, in the setting of the present experiment, the use of water content as a covariate is not possible. Foremost, it is a controlled variable (so it has a role of given data). In the second place, it has a restricted scale, being a dichotomy, distinguishing 'flooding' and 'non-flooding'. However, these characterizations can be changed by another experimental setup. For a further elaboration of the effect of water content there are two options to refine the experiment. Therefore, one needs to distinguish controllable variables (which are controlled by the experimental setting) form uncontrollable variables (which are outcomes from the experiment), and decide whether the water amount takes the role of a controlled variable or remains uncontrolled, being then electable as covariate.

(A) The first option is to refine the scale of water content as controllable variable, beyond the dichotomy 'flooding / non-flooding' as in the present study, but choosing a broader scale, where several levels of water (for instance 3 or 4 levels) including one in normal conditions of water are considered. Then, the covariance analysis will take the form of a bi-factorial analysis, where one factor consists of the varieties with six levels (corresponding to the six varieties) and the second factor is the water content at different levels.

(B) The second option is to design the water content as an uncontrolled variable. This corresponds to an experimental setting, where there is no planned control on the water amount, but the water charge depends on the rain, which then needs to be measured for the records. Giving up the control over the water amount would increase the overall variance of the dependent variable, thus an inclusion of the water content as additional covariate might in return reduce the variance. Still, the number of stalks is supposed to remain a better suited covariate since it gives a better prediction to the cane weight per hectare as the dependent variable, whereas environmental variables have a less direct impact, e.g. it impact does not depend only on the overall water amount, but also on its temporal distribution.

There are several variants on how to extend the present study. To give another idea, one can speculate whether the effect of the amount of rain on the yield is linear or non-linearly but smoothly, or even discontinuously increases at a threshold value. An option is to extend the study to different places with different soil and micro-climatic conditions. In any case, to obtain more robust data, the experiment should be repeated over a couple of years. Eventually, other environmental variables as the average daily temperature or the hours of sun might also be considered.

\section{ACKNOWLEDGMENTS}

This work is a result of the interuniversity network between universities of Argentina, Chile, Cuba and Ecuador, which in turn has been temporarily supported by the project 'Virtual Classroom of Mathematics and Mentoring', financed by the ALFA III program of the European Union.

\section{REFERENCES}

Amaya, A.E., Cock, J.H, Del Pilar, A.H. and Irvine, J.E. (1995). Biología. En: El cultivo de la caña en la zona azucarera de Colombia. Casslett, C. D.; J. T. Aguas and C. Isaacs, Centro de Investigaciones de la Caña de Azúcar de Colombia (CENICAÑA). Cali, Colombia. 412 pp.

Badii, M.H., Castillo, J. and Wong, A. (2008). Uso de Análisis de Covarianza (ANCOVA) en investigación científica (Use of covariance analysis (ANCOVA) in scientific research). Innovaciones de Negocios 5(1), $25-38$.

Balzarini, M.G., Gonzalez, L., Tablada, M., Casanoves, F., Di Rienzo, J.A., Robledo, C.W. (2008). Manual del Usuario, Editorial Brujas, Córdoba, Argentina.

Bernal, N., Morales, F., Gálvez, G. and Jorge, I. (1997). Variedades de caña de azúcar. Uso y manejo. Instituto Nacional de Investigaciones de la Caña de Azúcar. IMAGO. 99 pp.

Cock, J.H. (2003). Sugarcane growth and development. International Sugar Journal, 105, 540-552. 
S. Rodríguez et al., Covariance analysis of sugarcane variety experiments

DeLury, D.B. (1948). The Analysis of Covariance. Biometrics Vol. 4, No. 3 (Sep.), 153-170.

Deren, C.W., Cherry, R.H. and Snyder, G.H.. (1993). Effect of flooding on selected sugarcane clones. Journal American Society of Sugar Cane Technology, 13, 22-26.

Di Rienzo J.A., Casanoves F., Balzarini M.G., Gonzalez L., Tablada M., Robledo C.W. (2013). InfoStat, versión 2013, Grupo InfoStat, Facultad de Ciencias Agropecuarias, Universidad Nacional de Córdoba, Argentina. URL http://www.infostat.com.

Driessen, P., Deckers, J., Sparargaren, O. and Nachtergaele, F. (2001). Lecture notes on the major soils of the world. World Soil Resources Reports. 94. FAO. 334 pp.

Fairfield, S.H. (1957). Interpretation of Adjusted Treatment Means and Regressions in Analysis of Covariance. Biometrics. Vol. 13, No. 3, Special Issue on the Analysis of Covariance (Sep.), 282-308.

Humbert, R.P. (1965). El cultivo de la caña de azúcar. Edit. Universitaria. La Habana. 785 pp.

Federer, W.T. and Schlottfeldt, C.S. (1954). The use of covariance to control gradients in experiments. Biometrics, 10, 282-290.

Finney, D.J. (1946). Standard errors of yields adjusted for regression on an independent measurement. Biometrics Bull, 2, 53-55.

INICA. (2002). Normas y procedimientos del programa de mejoramiento genético de la caña de azúcar en Cuba. Boletín No. 1 Cuba \& Caña-INICA. Instituto Nacional de Investigaciones de la Caña de Azúcar. 315 pp.

Jorge, H., Morales, F., Jorge, and I. García, H. (2004). Catálogo de nuevas variedades de caña de azúcar. Publicaciones INICA. 105 pp.

Outhwaite, A.D. and Rutherford, A. (1955). Covariance analysis as alternative to stratification in the control of gradients. Biometrics, 11, 431-440.

Rayner, A.A., Bingham, C. and Fienberg, E.S. (1991). Testing hierarchical treatment components in analysis of covariance. Vol. 47, No. 3 (Sep.), 1183-1191.

Reynoso, A. (1963). Ensayo sobre el cultivo de la caña de azúcar. Editorial Nacional de Cuba. La Habana. 520 pp.

Rodríguez, S. (2008). Cambios morfofisiológicos en seis genotipos de caña de azúcar (Saccharum spp. Híb.) inducidos por sobrehumedecimiento de un suelo Vertisol. Tesis presentada en opción al grado científico de doctor en ciencias agrícolas. Universidad de Granma-Instituto Nacional de Ciencias Agrícolas. Cuba. 100 pp.

Samuels, D. A. (1979). Evaluation of cane brunding plants. Proceeding ISSCT XXV Congress, Durban, South Africa, 67-81.

Soil Survey Staff. (2003). Claves para la taxonomía de suelos. Colegio de Postgraduados, Chapingo, México. $306 \mathrm{pp}$.

Snedecor, G. W. and Cochran, W. G. (1980). Statistical methods. 7th ed. Iowa State University Press, Ames, IA.

Van Dillewijn C. (1951). Botánica de la caña de azúcar. Edición Revolucionaria. Instituto Cubano del Libro. Segunda Edición. 460 pp.

Wishart, J. (1936). Test of significance in the analysis of covariance. J. Roy. Stat. Soc. Suppl, 3, 79-82.

World Sugar Statistics. (2003). Agra Europe (London) LTD, FO Licht GmbH, UK. 12 pp 